\title{
Gambaran Pengetahuan Tentang Prebiotik Jahe Untuk Penurunan Nyeri Haid Pada Mahasiswi Diii Kebidanan Universitas Ngudi Waluyo Ungaran
} Tahun 2021

\author{
Atika Purnama Sari ${ }^{1}$, Rini Susanti ${ }^{2}$ \\ ${ }^{1,2}$ Program Studi Kebidanan Program Sarjana, Fakultas Kesehatan Universitas \\ Ngudi Waluyo \\ Email : atika.sasa.purnamasari@gmail.com, rinisusanti@gmailunw.ac.id
}

\begin{abstract}
ABSTRAK
Menurut WHO, didunia disminore angka kejadiannya cukup tinggi. Kejadian dismenorea pada perempuan muda rata-rata:16,8\%-81\%. Rata-rata di negara Eropa nyeri haid terjadi pada perempuan 45-97\%. Prevelensi terendah Bulgaria 8,8\%, tertinggi mencapai 94\% dinegara Finlandia. Prevelensi dismenorea tertinggi sering ditemui pada remaja perempuan, yang diperkirakan: $20-90 \%$. Sekitar $15 \%$ remaja mengalami dismenorea berat (Sulistyorinin, 2017). Tujuan penelitian ini untuk mengetahui Pengetahuan Mahasiswi tentang Prebiotik Jahe Untuk Penurunan Nyeri Haid di Mahasiswi DIII Kebidanan Universitas Ngudi Waluyo Ungaran Tahun 2021. Penelitian deskriptif kuantitatif dengan Survey. Sampel pada penelitian ini adalah mahasiswi DIII kebidanan Universitas Ngudi Waluyo Ungaran sejumlah 32 mahasiswi. Teknik pengambilan sampel dengan Sampling Total. Analisa data menggunakan distribusi frekuensi. Hasil penelitian ini kemudian diberi interpretasi berdasarkan variabel yang diteliti berdasarkan kriteria baik, cukup dan kurang. Hasil penelitian ini menunjukkan bahwa mahasiswi DIII kebidanan Universitas Ngudi Waluyo Ungaran memiliki pengetahuan tentang Prebiotik Jahe Untuk Penurunan Nyeri Haid, pengetahuan keseluruhan baik dengan jumlah 32 orang $(100,0 \%)$. Bagi mahasiswi untuk lebih meningkatkan pengetahuannya tentang kesehatan khususnya tentang Prebiotik Jahe Untuk Penurunan Nyeri Haid yaitu dengan mempraktikkan cara pengolahannya setiap datang bulan dengan herbal.
\end{abstract}

\section{Kata kunci : Pengetahuan, Prebiotik Jahe, Penurunan Nyeri Haid.}

\begin{abstract}
An Overview of Knowledge About Prebiotic Ginger for Reducing Menstrual Pain in Diii Midwifery Students at Ngudi Waluyo University Ungaran in 2021

According to $\mathrm{WHO}$, in the world the incidence rate is quite high. The incidence of dysmenorrhoea in young women on average: $16.8 \%-81 \%$. The average in European countries menstrual pain occurs in women 45-97\%. The lowest Bulgarian prevalence is $8.8 \%$, the highest is $94 \%$ in Finland. The highest prevalence of dysmenorrhea is often found in adolescent girls, which is estimated: 20-90\%. About 15\% of adolescents have severe dysmenorrhea (Sulistyorinin, 2017). The purpose of this study was to determine the knowledge of students about ginger prebiotics to reduce menstrual pain in students of DIII Midwifery, Ngudi Waluyo Ungaran University in 2021. Quantitative descriptive research with survey. The sample in this study were 32 female students of DIII midwifery, Ngudi Waluyo
\end{abstract}

Gambaran Pengetahuan Tentang... Atika Purnama Sari, Rini Susanti Journal of Holistics and Health Sciences Vol. 3, No. 2 September 2021 
Ungaran University. Sampling technique with sampling Total. Data analysis using frequency distribution. The results of this study are then given an interpretation based on the variables studied based on the criteria of good, adequate and insufficient. The results of this study indicate that students of DIII midwifery at Ngudi Waluyo Ungaran University have knowledge of Ginger Prebiotics for Menstrual Pain Reduction, the overall knowledge is good with a total of 32 people (100,0\%). For female students to further improve their knowledge about health, especially about ginger prebiotics to reduce menstrual pain, by practicing how to process them every month with herbs.

\section{Keywords : Knowledge, Ginger Prebiotics, Decreasing Menstrual Pain.}

\section{PENDAHULUAN}

Nyeri haid merupakan nyeri yang berada diperut bawah. Nyeri haid ini muncul sebelum dan ketika haid. Pada sebagian perempuan, dismenore ada yang bersifat ringan, dan juga ada yang berlebihan sehingga mengganggu aktivitas sehari-hari (Alodokter, 2019). Dalam penelitian Sulistyorinin, (WHO), mengatakan dimana angka kejadian dismenore diseluruh dunia cukup tinggi. Rata-rata dari insidensi atau kejadian terjadinya dismenore pada perempuan muda yaitu antara $16,8 \%$ $-81 \%$, dan rata-rata di negara Eropa dismenore terjadi pada $45 \%-97 \%$ pada perempuan. Prevalensi nyeri haid tertinggi sering ditemui pada remaja perempuan, yang diperkirakan antara 20\%-90\%. Sekitar $15 \%$ remaja dilaporkan mengalami dismenore atau nyeri haid yang berat. Di Amerika Serikat, nyeri haid diakui sebagai penyebab paling sering ketidakhadiran atau tidak masuk di sekolah yang dialami remaja perempuan. Selain itu, juga dilakukan survey pada 113 perempuan Amerika Serikat dan dinyatakan proporsi sebanyak 29\%-44\%, paling banyak pada umur 18-45 tahun (Sulistyorinin, 2017).

Dalam penelitian (Purnomo, 2011) dalam Salamah (Ed.), di Indonesia sendiri, angka terjadinya nyeri haid atau dismenorea sebanyak $55 \%$ terjadi pada dikalangan usia produktif, yaitu $15 \%$ diantaranya, mengatakan bahwa aktivitas menjadi terbatas akibat nyeri haid atau dismenore. Beberapa penelitian tentang nyeri haid pada remaja menunjukkan populasi cukup tinggi.

Berdasarkan Studi Pendahuluan dalam penelitian ini adalah karena Nyeri haid atau Dismenorea merupakan keluhan yang rata-rata sering di alami oleh setiap remaja putri. Dari Kuesioner yang telah diisi mahasiswi didapatkan bahwa program yang di lakukan untuk penatalaksanaan dismenorea antara lain menggunakan farmakologi dan non farmakologi: salah satunya bisa menggunakan prebiotic jahe. Jahe dapat menurunkan nyeri haid atau dismenorea sesuai dengan penelitian (Ati Karomika, Ari Yuniastuti, 2019).

Dari data kuesioner yang terkumpul tersebut juga diketahui terdapat 32 mahasiswi mengalami nyeri haid. Remaja Putri yang beresiko mengalami dismenorea atau nyeri haid umumnya disebabkan karena adanya siklus menstruasi yang lama, ketidakteraturan dalam melakukan olahraga, usia yang terlalu cepat mengalami menstruasi, dan status gizi yang tidak normal hal ini sesuai dengan (Nurwana, Yusuf Sabilu, 2017). 
Berdasarkan data diatas maka perlu dilakukan penelitian Gambaran Pengetahuan Tentang Prebiotik Jahe Untuk Penurunan Nyeri Haid Pada Mahasiswi DIII Kebidanan Universitas Ngudi Waluyo Ungaran Tahun 2021 di Jl Diponegoro No.186 Ungaran, Kab. Semarang.

\section{METODE PENELITIAN}

Desain penelitian deskriptif dengan pendekatan cross sectional. Populasi pada penelitian ini adalah mahasiswi DIII Kebidanan Universitas Ngudi Waluyo Ungaran. Sampel pada penelitian ini adalah 32 mahasiswi DIII Kebidanan Universitas Ngudi Waluyo Ungaran. Teknik pengambilan sampel dengan Sampling Total. Instrumen penelitian adalah kuesioner. Analisa data menggunakan uji chisquare.

\section{HASIL DAN PEMBAHASAN}

\section{Karakteristik Responden}

Tabel 1 Karakteristik Responden

\begin{tabular}{lcc}
\hline \multicolumn{1}{c}{ Karakteristik Responden } & Frekuensi & Persentase (\%) \\
\hline Usia & 5 & 15,63 \\
<20 Tahun & 27 & 84,37 \\
>20 Tahun & & \\
Pendidikan & 18 & 56,25 \\
SMA & 7 & 21,875 \\
MA & 7 & 21,875 \\
SMK & & \\
\hline
\end{tabular}

Berdasarkan tabel 1 di atas menunjukkan bahwa sebagian besar responden masuk dalam usia lebih dari 20 tahun yaitu sejumlah 27 responden $(84,37 \%)$, dan sebagian kecil responden masuk dalam usia kurang dari 20 tahun yaitu sejumlah 5 responden $(15,63 \%)$. Umur merupakan usia dari individu dimana umur dihitung mulai dari seseorang saat atau ketika dilahirkan sampai ulang tahun. Ketika umur seseorang sudah mencukupi, maka tingkat pengetahuan, kekuatan, dan kematangan dari seseorang maka cara berfikir maupun bekerja akan semakin matang (Notoatmojo, 2011). Sebagian besar responden merupakan lulusan dari SMA yaitu sejumlah 18 responden $(56,25 \%)$, sebagian kecil responden yang lulusan MA ada 7 responden $(21,875 \%)$, dan sebagian kecil responden yang merupakan lulusan SMK yaitu ada 7 responden (21,875\%). Pendidikan merupakan bimbingan yang diberikan seseorang terhadap perkembangan orang lain menuju kearah cita-cita tertentu yang menentukan manusia untuk berbuat dan mengisi kehidupan untuk mencapai keselamatan dan kebahagiaan. Pendidikan diperlukan untuk mendapatkan informasi meliputi hal-hal yang menunjang Kesehatan sehingga dapat menngkatkan kualitas hidup (Dewi, 2011). 


\section{Analisis Univariat}

a. Pengetahuan Mahasiswi DIII Kebidanan Universitas Ngudi Waluyo Ungaran Tahun 2021 Tentang Prebiotik Jahe Untuk Penurunan Nyeri Haid

Tabel 2 Distribusi Frekuensi Berdasarkan Pengetahuan Mahasiswi tentang Pengertian Jahe di DIII Kebidanan Universitas Ngudi Waluyo Ungaran Tahun 2021

\begin{tabular}{ccc}
\hline $\begin{array}{c}\text { Pengetahuan tentang } \\
\text { Pengertian Jahe }\end{array}$ & Frekuensi & Persentase (\%) \\
\hline Baik & 32 & 100,0 \\
\hline Jumlah & $\mathbf{3 2}$ & $\mathbf{1 0 0 , 0}$ \\
\hline
\end{tabular}

\begin{tabular}{lrr}
\multicolumn{1}{c}{$\begin{array}{c}\text { Berdasarkan } \\
\text { menunjukkan }\end{array}$} & $\begin{array}{r}\text { tabel } 2 \\
\text { bahwa } \\
\text { keseluruhan }\end{array}$ \\
Mahasiswi Dengetahuan & DIII Kebidanan \\
Universitas & Ngudi & waluyo \\
Ungaran & Tahun & 2021 \\
mempunyai & tingkat \\
pengetahuan baik tentang \\
prebiotic jahe sejumlah 32 \\
responden (100,0\%) memiliki \\
pendidikan Aktif di
\end{tabular}
Universitas Ngudi Waluyo. Pengetahuan Mahasiswi tentang Prebiotik Jahe yang meliputi pengertian jahe, gambaran tanaman jahe, Jahe Terdapat Tiga Jenis Dan Masing-masing Karakteristik Beda Pedasnya, jahe untuk penggunaan sehari-hari, kandungan jahe yang menyehatkan, manfaat jahe bagi kesehatan, cara pemberian prebiotic jahe, ini di sebabkan karena setiap orang dapat memperoleh pengetahuan dari bangku kuliah, melihat berita di televisi, membaca koran, mendengarkan radio, dan mendapatkan informasi dari tetangga, saudara ataupun dari orang lain. Hal ini sesuai dengan pendapat Dewi (2011) pengetahuan di pengaruhi oleh factor Pendidikan formal. Penegtahuan sangat erat hubungannya dengan Pendidikan, dimana diharapkan bahwa dengan Pendidikan yang tinggi maka orang tersebut akan semakin luas pula pengetahuannya. Akan tetapi perlu ditekankan, bukan berarti seseorang yang berpendidikan rendah mutlak berpengetahuan rendah pula. Hal ini mengingat bahwa peningkatan pengetahuan tidak mutlak diperoleh melalui Pendidikan non formal.

b. Pengetahuan Mahasiswi tentang Pengertian Jahe

Tabel 3 Distribusi Frekuensi Berdasarkan Pengetahuan Mahasiswi tentang Pengertian Jahe di DIII Kebidanan Universitas Ngudi Waluyo Ungaran Tahun 2021

\begin{tabular}{ccc}
\hline $\begin{array}{c}\text { Pengetahuan tentang } \\
\text { Pengertian Jahe }\end{array}$ & Frekuensi & Persentase (\%) \\
\hline Baik & 32 & 100,0 \\
\hline Jumlah & $\mathbf{3 2}$ & $\mathbf{1 0 0 , 0}$ \\
\hline
\end{tabular}

Berdasarkan tabel 3

menunjukkan bahwa hasil 
keseluruhan yaitu 32

merupakan tumbuhan responden $\quad(100,0 \%)$, rumpun, tumbuhan ini memiliki tingkat pengetahuan terdapat batang yang semu kategori baik. Sehingga dalam dan tanaman rimpang popular hal ini mengetahui tentang Jahe, dimana jahe sendiri memiliki nama ilmiah Zingiber Officinale di kalangan masyarakat untuk rempah dapur atau sebagai bahan obat (Ramadhan, 2013).

\section{c. Pengetahuan Mahasiswi tentang Gambaran Tanaman Jahe}

Tabel 4 Distribusi Frekuensi Berdasarkan Pengetahuan Mahasiswi tentang Gambaran Tanaman Jahe di DIII Kebidanan Universitas Ngudi Waluyo Ungaran Tahun 2021

\begin{tabular}{ccc}
\hline $\begin{array}{c}\text { Pengetahuan Tentang Gambaran } \\
\text { Tanaman Jahe }\end{array}$ & Frekuensi & Persentase (\%) \\
\hline Cukup & 2 & 6,2 \\
Baik & 30 & 93,8 \\
\hline Jumlah & $\mathbf{3 2}$ & $\mathbf{1 0 0 , 0}$ \\
\hline
\end{tabular}

Berdasarkan tabel 4

menunjukkan hasil

keseluruhan yaitu 30

responden $\quad(93,8 \%)$

memiliki pengetahuan

baik, sebanyak 2

responden $\quad(6,2 \%)$

berpengetahuan cukup.

Menurut Ramadhan,

(2013) Jahe yaitu

tumbuhan berbatang

semu, daun cenderung

halus tangkainya serta

ada bulu mikro. Jahe akarnya membentuk umbi, dikenal dengan rimpang jahe sering untuk bahan obat. Ciri-ciri umum dari tanaman jahe bisa dikenali dari tanaman jahe: Jahe adalah masuk kedalam tanaman herbal yang bisa tumbuh dengan 30 hingga $100 \mathrm{~cm}$ tingginya. Jahe bersifat semu, memiliki warna hijau dan beralur batang tanamannya.

\section{d. 3 Jenis Jahe Dan Karakteristik Masing-masing Pedasnya Beda}

Tabel 5 Distribusi Frekuensi Berdasarkan Pengetahuan Mahasiswi tentang 3 Jenis Jahe Dan Karakteristik Masing-masing Pedasnya Beda di DIII Kebidanan Universitas Ngudi Waluyo Ungaran Tahun 2021

\begin{tabular}{ccc}
\hline $\begin{array}{c}\text { Pengetahuan tentang 3 Jenis Jahe } \\
\text { Dan Karakteristiknya }\end{array}$ & Frekuensi & Persentase (\%) \\
\hline Baik & 32 & 100,0 \\
\hline Jumlah & $\mathbf{3 2}$ & $\mathbf{1 0 0 , 0}$ \\
\hline
\end{tabular}

Berdasarkan tabel 5 menunjukkan Hasil penelitian menunjukan bahwa pengetahuan responden tentang 3 Jenis Jahe Dan Karakteristik Masing-masing Pedasnya Beda. keseluruhan responden berpengetahuan baik sebanyak 32 responden (100,0\%). Menurut Ramadhan, (2013) jahe dapat dibedakan menjadi tiga jenis berdasarkan ukuran, bentuk dan warna rimpangnya. Ketiga jenis itu: jahe putih, jahe kuning kecil dan jahe 
merah, pada penelitian yang telah dilalukan oleh Tim Lentera Jahe emprit dan jahe sunti didalamnya terdapat minyak atsiri: $1,5-3,8 \%$ dari berat keringnya. Jahe putih kecil, nama lain jahe jenis ini yaitu jahe sunti atau jahe emprit, jahe ini memiliki potongan melintang berwarna putih kekuningan, berbentuk agak pipih, berserat lembut, dengan aroma agak tajam, dan rasa yang pedas. Ini merupakan ragam Jamu Khas Indonesia. Pada umumnya jahe putih kecil dipanen dalam keadaan tua. Jenis jahe ini

e. Pengetahuan Mahasiswi Tentang Jahe Untuk Penggunaan Sehari-hari

Tabel 6 Distribusi Frekuensi Berdasarkan Pengetahuan Mahasiswi tentang Jahe Untuk Penggunaan Sehari-hari di DIII Kebidanan Universitas Ngudi Waluyo Ungaran Tahun 2021

\begin{tabular}{ccc}
\hline $\begin{array}{c}\text { Pengetahuan tentang } \\
\text { Jahe Untuk Penggunaan } \\
\text { Sehari-Hari }\end{array}$ & Frekuensi & Persentase (\%) \\
\hline Kurang & 1 & 3,1 \\
Cukup & 1 & 3,1 \\
Baik & 30 & 93,8 \\
\hline Jumlah & $\mathbf{3 2}$ & $\mathbf{1 0 0 , 0}$ \\
\hline
\end{tabular}

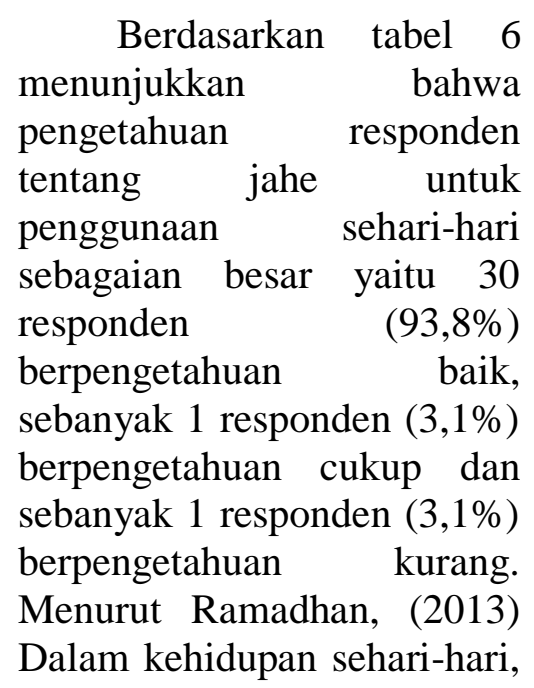

memiliki rasa lebih pedas dibandingkan jahe gajah, karena jahe putih kecil memiliki kandungan minyak atsiri yang lebih banyak dari pada jahe gajah. Jahe putih, jahe ini juga disebut dengan nama jahe kuning besar, jahe gajah, jahe Jahe putih atau jahe kuning besar, jahe gajah, jahe badak atau jahe kombongan. Jahe jenis ini memiliki rimpang yang besar serta gemuk, potongan melintang berwarna putih kekuningan, berserat sedikit dan lembut (Wijaya, 2020). jahe biasanya digunakan sebagai bumbu masak dan juga sebagai minuman penghangat badan. Jahe dapat membuat efek panas dalam perut, maka jahe untuk bahan minuman: sirup. Sebagai bahan minuman, jahe biasanya digunakan untuk menghangatkan badan sehingga bisa digunakan untuk meredakan masuk angin.

\section{f. Pengetahuan Mahasiswi tentang Kandungan Jahe Yang Menyehatkan}


Tabel 7 Distribusi Frekuensi Pengetahuan Mahasiswi tentang Kandungan Jahe Yang Menyehatkan di DIII Kebidanan Universitas Ngudi Waluyo Ungaran

Tahun 2021

\begin{tabular}{ccc}
\hline $\begin{array}{c}\text { Pengetahuan tentang Kandungan Jahe } \\
\text { Yang Menyehatkan }\end{array}$ & Frekuensi & $\begin{array}{c}\text { Persentase } \\
(\boldsymbol{\%})\end{array}$ \\
\hline Baik & 32 & 100,0 \\
\hline Jumlah & $\mathbf{3 2}$ & $\mathbf{1 0 0 , 0}$ \\
\hline
\end{tabular}

Berdasarkan tabel 7

menunjukkan pengetahuan

keseluruhan responden

berpengetahuan baik, 32

sampel $(100,0 \%)$ dalam

kategori baik. Menurut Putri, (2020) Sudah bukan rahasia jika jahe dianggap sebagai salah satu rempah paling menyehatkan, karena kabar turun-temurun. Khasiat jahe juga sudah terbukti secara ilmiah. Jahe juga mengandung komponen khas sangat baik untuk kesehatan, yaitu gingerol, komponen inilah yang bertanggung jawab atas sebagian besar manfaat yang bisa didapatkan dari mengonsumsi jahe. Kandungan jahe yang menyehatkan, dimana kurannya memang tidak besar, tapi jahe memiliki segudang kandungan yang bermanfaat bagi kesehatan, selain gingerol tentunya. Dalam satu sendok makan jahe segar saja sudah terdapat berbagai nutrisi, seperti: Kalori: 4,8, Karbohidrat: 1,07gram, Serat: 0,12gram, Protein: 0,11 gram, Lemak: 0,05 gram, Gula: 0,1 gram. Jahe juga mengandung berbagai vitamin dan mineral yang baik untuk tubuh, seperti: Zat besi, Kalium, Vitamin B3 dan B6, Vitamin C, Magnesium, Fosfor, Zinc, Folat, Riboflavin (vitamin B2), Niacin (vitamin B3).

\section{g. Pengetahuan Mahasiswi tentang Manfaat Jahe Bagi Kesehatan}

Tabel 8 Distribusi Frekuensi Pengetahuan Mahasiswi tentang Manfaat Jahe Bagi Kesehatan di DIII Kebidanan Universitas Ngudi Waluyo Ungaran Tahun 2021

\begin{tabular}{ccc}
\hline $\begin{array}{c}\text { Pengetahuan tentang Manfaat } \\
\text { Jahe Bagi Kesehatan }\end{array}$ & Frekuensi & $\begin{array}{c}\text { Persentase } \\
(\boldsymbol{\%})\end{array}$ \\
\hline Baik & 32 & 100,0 \\
\hline Jumlah & $\mathbf{3 2}$ & $\mathbf{1 0 0 , 0}$ \\
\hline
\end{tabular}

Berdasarkan tabel 8 menunjukkan bahwa pengetahuan keseluruhan responden baik, 32 responden (100,0\%). Berdasarkan jawaban responden didapatkan semua responden $(100,0 \%)$ menjawab dengan kategori baik. Jahe bermanfaat untuk redakan flu dan demam, jahe memiliki sejarah penggunaan, dimana pengunaannya sangat panjang dalam berbagai bentuk pengobatan tradisional atau alternatif. Tanaman ini mengandung gingerol yang memiliki sejumlah khasiat. Gingerol merupakan senyawa bioaktif utama dalam jahe, yang bertanggung jawab atas sebagian besar khasiat 
obatnya dan memiliki efek anti-inflamasi dan antioksidan kuat. Tanaman ini bermanfaat: membantu pencernaan, mengurangi mual, dan membantu melawan flu dan demam. Jahe mengobati mual, jahe sepertinya efektif melawan mual, terutama mual di pagi hari. Tanaman ini memiliki sejarah panjang digunakan sebagai obat mabuk laut. Jahe juga dapat meredakan mual sampai muntah setelah operasi, dan pada pasien kanker yang menjalani kemoterapi. Tapi mungkin yang paling efektif dalam hal mual yang berhubungan dengan kehamilan: mual di pagi hari. Ekstrak minyak jahe merah berfungsi untuk melindungi sistem pencernaan dari bakteri, sehingga mencegah dari masalah pencernaan: sakit perut dan lain sebagainya. Agen antibakteri yang ada didalam jahe dapat melawan bakteri jahat: Escherichia coli, Salmonella enteriditis, dan Staphylococcus aureus (Swari, 2020).

\section{h. Pengetahuan Mahasiswi tentang Cara Pemberian Prebiotik Jahe}

Tabel 9 Distribusi Frekuensi Pengetahuan Mahasiswi tentang Cara Pemberian Prebiotik Jahe di DIII Kebidanan Universitas Ngudi Waluyo Ungaran Tahun 2021

\begin{tabular}{ccc}
\hline $\begin{array}{c}\text { Pengetahuan tentang Manfaat Jahe Bgai } \\
\text { Kesehatan }\end{array}$ & Frekuensi & $\begin{array}{c}\text { Persentase } \\
(\boldsymbol{\%})\end{array}$ \\
\hline Baik & 32 & 100,0 \\
\hline Jumlah & $\mathbf{3 2}$ & $\mathbf{1 0 0 , 0}$ \\
\hline
\end{tabular}

Berdasarkan tabel 8 menunjukkan pengetahuan keseluruhan responden baik, sejumlah 32 responden $(100,0 \%)$. Berdasarkan jawaban responden didapatkan semua responden (100,0\%) menjawab dengan kategori baik. Dalam sebuah penelitian Internasional yang telah dilakukan oleh Jurusan Kebidanan Fakultas Ilmu Kesehatan Jenderal Achmad Yani Cimahi, Indonesia dengan judul penelitian Pengaruh Minum Jahe Merah Terhadap Penurunan Intensitas Nyeri Dismenore. Hasil penelitian menunjukkan bahwa ada pengaruh pemberian minuman jahe merah terhadap penurunan intensitas nyeri dismenore dengan nilai median sebelum diberikan minuman jahe merah dengan intensitas nyeri 5 dan setelah diberikan minuman jahe dengan nilai median sebesar intensitas nyeri, sehingga dapat di simpulkan bahwa berdasarkan hasil penelitian bahwa intensitas nyeri dismenore setelah pemberian Jahe merah tingkat nyeri menurun sedang hingga ringan, sehingga keefektifan minuman jahe merah untuk menurunkan intensitas nyeri pada remaja putri (Indria Astuti, Rika Nur Hasanah, 2019). Dalam sebuah penelitian Nasional yang telah dilakukan oleh Akademi Kebidanan Sakinah Passuruan, dengan judul penelitian Efektifitas 
Pemberian Ekstraks Jahe Terhadap Intensitas Dismenore Pada Mahasiswi Akademi Kebidanan Sakinah Pasuruan. Hasil penelitian menunjukkan Ekstrak jahe dapat di intervensi efektif sebagai menurunkan nyeri dismenorea. Dalam hal ini juga ekstrak jahe dapat dipergunakan untuk pengobatan herbal dalam mengurangi nyeri haid (Rahayu \& Nujulah, 2018). Dalam sebuah penelitian Internasional yang telah dilakukan oleh Universitas Negeri Semarang pada siswi SMK 2 AlHikmah 1 Sirampog, dengan judul penelitian The

\section{KESIMPULAN}

Berdasarkan dari penelitian yang telah dilakukan, dengan judul Gambaran Pengetahuan Tentang Prebiotik Jahe Untuk Penurunan Nyeri Haid Pada Mahasiswi DIII Kebidanan Universitas Ngudi Waluyo Ungaran Tahun 2021, sehingga ditarik kesimpulan bahwa keseluruhan Pengetahuan Mahasiswi DIII Kebidanan Universitas Ngudi Waluyo Ungaran Tahun 2021 Tentang Prebiotik Jahe Untuk Penurunan Nyeri Haid keseluruhan dalam kategori Baik yaitu sejumlah 32 Mahasiswi (100,0\%), keseluruhan Pengetahuan Mahasiswi DIII Kebidanan Universitas Ngudi Waluyo Ungaran Tahun 2021 Tentang Pengertian Jahe, keseluruhan dalam kategori baik yaitu sejumlah 32 Mahasiswi (100,0\%), sebagaian besar Pengetahuan Mahasiswi DIII Kebidanan Universitas Ngudi Waluyo Ungaran Tahun 2021 Tentang Gambaran Tanaman Jahe,
Comparison in The Effectiveness of Warm and Ginger Compresses to The Menstruation Pain Toward The Students of Smk 2 AlHikmah 1 Sirampog. Hasil penelitian

menunjukkan bahwa ada penurunan tingkat nyeri setelah diberikan kompres jahe skala 0 (tidak nyeri). Rata-rata tingkat nyeri pada kompres jahe $(0,625)$ dan kompres hangat $(1,375)$, sehingga dapat disimpulkan bahwa kompres jahe lebih efektif untuk meredakan nyeri (Ati Karomika, Ari Yuniastuti, 2019).

Sebagian besar dalam kategori baik yaitu sejumlah 30 Mahasiswi (93,8\%), keseluruhan Pengetahuan Mahasiswi DIII Kebidanan Universitas Ngudi Waluyo Ungaran Tahun 2021 Tentang 3 Jenis Jahe Dan Karakteristik Masing-masing Pedasnya Beda, keseluruhan dalam kategori baik yaitu sejumlah 32 Mahasiswi (100,0\%), sebagaian besar Pengetahuan Mahasiswi DIII Kebidanan Universitas Ngudi Waluyo Ungaran Tahun 2021 Tentang Jahe Untuk Penggunaan Sehari-hari, sebagaian besar dalam kategori baik yaitu sejumlah 30 Mahasiswi (93,8\%), keseluruhan Pengetahuan Mahasiswi DIII Kebidanan Universitas Ngudi Waluyo Ungaran Tahun 2021 Tentang Kandungan Jahe Yang Menyehatkan, keseluruhan dalam kategori baik yaitu sejumlah 32 Mahasiswi (100,0\%), keseluruhan Pengetahuan Mahasiswi DIII Kebidanan Universitas Ngudi 
Waluyo Ungaran Tahun 2021 Tentang Manfaat Jahe Bagi Kesehatan, keseluruhan dalam kategori baik yaitu sejumlah 32 Mahasiswi (100,0\%), keseluruhan Pengetahuan Mahasiswi DIII Kebidanan Universitas Ngudi Waluyo Ungaran Tahun 2021 Tentang Cara Pemberian Prebiotik Jahe, keseluruhan dalam kategori baik yaitu sejumlah 32 Mahasiswi $(100,0 \%)$.

\section{UCAPAN TERIMA KASIH}

Puji syukur penulis panjatkan kehadirat Allah SWT sebagai zat yang memberikan kenikmatan, baik nikmat kesehatan, kesabaran, ketelatenan, dan kekuatan kepada hambanya sehingga didalam penyusunan artikel penelitian dengan sub judul Gambaran Pengetahuan Tentang Prebiotik Jahe Untuk Penurunan Nyeri Haid Pada Mahasiswi DIII Kebidanan Universitas Ngudi Waluyo Ungaran Tahun 2021, berjalan dengan lancar tanpa ada halangan suatu apapun dan selesai tepat pada waktunya. Solawat dan salam penulis panjatkan kepada nabi Aggung Muhammad SAW dan sahabat nabi. Dengan hormat, pada kesempatan kali ini penulis menyampaikan rasa terima kasih yang sebesar-besarnya dan penghargaan yang setinggi-tingginya kepada pembimbing Ibu Rini Susanti, S.Si.T.,M.Kes. selaku dosen pembimbing dari Universitas Ngudi Waluyo, yang telah meluangkan waktunya untuk memberikan petunjuk, dorongan, saran dan arahan dari awal penelitian ini hingga selesainya penulisan artikel. Penulis ucapkan terima kasih kepada responden yang telah bersedia berpartisipasi mengikuti acara pengisian kuisioner secara daring ini hingga selesai, semoga ilmunya bermanfaat dan bisa selalu di terapkan untuk penurunan nyeri haid, amin.

\section{DAFTAR PUSTAKA}

Ati Karomika, Ari Yuniastuti, R. S. R. R. (2019). The Comparison in The Effextiveness of Warm and Ginger Compressan to The Menstruation Pain Toward The Students of Smk 2 Al-Hikmah 1 Sirampong. Public Health Perspectives Journal, 2(1), 278. https://doi.org/10.22216/jen.v2 i1.278

Dewi, A. W. D. (2011). Pengetahuan, Sikap Dan Perilaku Manusia. Yogyakarta: Nuha Medika.

Indria Astuti, Rika Nur Hasanah, \& R. (2019). The Influence Of Red Ginger Dringking Towards Degration Dismenorea Pain Intensity. Third International Seminar On Global Health Tecnology Transformation in Healthcare For a Better Life, 3(1), 27-30.

Notoatmojo, S. (2011). PronsipPrinsip Dasar Ilmu Kesehatan Masyarakat. Jakarta: PT Rineka Cipta.

Nurwana, Yusuf Sabilu, A. F. F. (2017). Analisis Faktor Yang Berhubungan Dengan Kejadian Disminorea Pada Remaja Putri Di Sma Negeri 8 Kendari Tahun 2016. Ilmiah Mahasiswa Kesehatan Masyarakat, 2(6), 114.

https://www.neliti.com/id/publi cations/185630/analisis-faktoryang-berhubungan-dengankejadian-disminorea-padaremaja-putri-di 
Purnomo, I. (2011). "Hubungan pengetahuan dan sikap remaja putri dengan penanganan keluhan nyeri haid ( dysmenorhe ) di SMPN 09 kelas viii kota Pekalongan". Dalam Salamah, U (Ed.). Hubungan Pengetahuan dan Sikap Remaja Putri terhadap Perilaku Penanganan Dismenore. Ilmiah Kebidanan Indonesia, 9(03), 123-127. https://doi.org/10.33221/jiki.v9i 03.382

Putri, N. H. (2020). Ragam Kandungan Jahe yang Memberikannya Segudang Manfaat. Diakses pada 23 Oktober 2020, dari https://www.sehatq.com/artikel/ ragam-kandungan-jahe-yangmemberikannya-segudangmanfaat.

Rahayu, K. D., \& Nujulah, L. (2018). Efektifitas Pemberian Extrak Jahe Terhadap Intensitas Dismenorea Pada Mahasiswi Akademi Kebidanan Sakinah Pasuruan. Kebidanan, 10(2), 6972.

https://doi.org/10.36456/embrio. v10i2.1642

Ramadhan, A. J. (2013). Aneka Manfaat Ampuh Rimpang Jahe Untuk Pengobatan. Yogyakarta: Diandra Pustaka Indonesia.

Sulistyorinin. (2017). Buku Ajar Ketrampilan Dasar Praktik Klinik Kebidanan. Yogyakarta: Pustaka Rihanna.

Swari, R. C. (2020). Manfaat Jahe Merah untuk Kesehatan, dari Pencernaan Hingga Kesuburan. Diakses pada 18 Desember 2020, dari https://hellosehat.com/nutrisi/fa kta-gizi/manfaat-jahe-merahkesehatan/\#gref.

Wijaya, Y. G. (2020). 3 Jenis Jahe dan Karakteristik Masingmasing, Pedasnya Beda! Diakses pada 23 Oktober 2020, dari https://travel.kompas.com/read/ 2020/03/25/150100527/3-jenisjahe-dan-karakteristik-masingmasing-pedasnyabeda?page $=$ all . 